\title{
Corrosion initiation in cracked fibre reinforced concrete: influence of crack width, fibre type and loading conditions
}

\author{
Carlos G. Berrocal ${ }^{\mathrm{a}, \mathrm{c}, *}$, Ingemar Löfgren ${ }^{\mathrm{a}, \mathrm{c}}$, Karin Lundgren $^{\mathrm{a}}$, Luping Tang ${ }^{\mathrm{b}}$ \\ ${ }^{a}$ Division of Structural Engineering, Chalmers University of Technology \\ ${ }^{b}$ Division of Building Technology, Chalmers University of Technology \\ ${ }^{c}$ Thomas Concrete Group AB
}

\begin{abstract}
This paper reports results from an ongoing project aimed at investigating the influence of fibre reinforcement on corrosion of rebar in chloride environments. Material tests showed that the resistivity of concrete decreased with the addition of fibres, whereas the chloride migration coefficient remained unaffected. Fibres at low dosages $(<1.0 \%$ vol.) did not significantly affect the compressive and flexural strength of concrete but greatly enhanced its toughness. The results from corrosion tests showed a tendency of an earlier initiation of corrosion with increasing crack widths, while a small improvement was observed by the addition of fibres in terms of delayed corrosion initiation.
\end{abstract}

Keywords: A. Steel reinforced concrete, C. Atmospheric corrosion

\section{Introduction}

Today, corrosion of reinforcement remains a major problem affecting the durability of reinforced concrete structures, where chloride ingress is one of the primary causes [1]. In corrosion terms, the service life of a reinforced concrete $(\mathrm{RC})$ structure can, generally, be divided into two periods of time: initiation and propagation [2]. The initiation period is considered the time required by external agents to penetrate into the concrete and cause the depassivation of the reinforcing steel. The propagation period is characterized by active corrosion, with associated steel loss of cross-sectional area of the bars and the gradual accumulation of corrosion products causing cracking and spalling of the concrete cover, both of which lead to a reduction of structural safety.

In sound concrete, the concrete cover acts as a physical barrier against the ingress of corrosioninducing agents such as oxygen, moisture and chloride ions. Therefore, the cover depth and quality of concrete are the most important factors influencing the corrosion process of reinforcement. In practice, however, cracks originating

*Corresponding author. Tel: +46 317722262

Email address: carlos.gil@chalmers.se (Carlos G. Berrocal) from shrinkage, thermal gradients and/or mechanical loading are present in the vast majority of reinforced concrete structures. These cracks often become preferential paths for the ingress of external agents. As a result, the transport properties of concrete are significantly altered [3, 4, 5] and the durability of concrete structures is negatively affected. Consequently, in current structural codes [6, 7], the crack width on the concrete surface is limited as a way of trying to obtain durable structures.

The relation between the corrosion of reinforcement and cracking has been investigated by numerous authors (see e.g. [2, 8, 9, 10, 11, 12]). Whereas most observations indicate that wider cracks tend to hasten the initiation of corrosion , researchers are still debating whether the surface crack width influences the corrosion rate during the propagation phase. Further investigations indicate that other parameters such as crack frequency [13], crack orientation (with respect to reinforcement) [14], crack self-healing [15], the stress level at the reinforcement [16] or the condition of the concrete-reinforcement interface [17, 18, 19] may each have higher impact on the corrosion process. 
The addition of fibres into concrete improves its toughness and tensile properties. Moreover, fibre reinforced concrete has proven to be successful in arresting crack propagation in concrete members reinforced with conventional rebar, leading to narrower and closely spaced cracks compared to plain concrete, even for low fibre contents $(<1 \%)$. It has also been reported that fibres can reduce the interfacial degradation between the concrete and the reinforcement (slip and separation) caused by mechanical loading [20]. Furthermore, while chloride diffusion in sound concrete seems to remain unaffected by the presence of fibres, permeation in cracked concrete has been found to decrease when fibres are added [21, 22].

Over the past years, a number of studies have been carried out to investigate whether the improvements observed when adding fibre reinforcement to concrete could also be beneficial with regard to mitigating the corrosion of steel bars. Reported results indicate that fibres could have a positive effect on the corrosion rate; by arresting the growth of cracks originated from tensile splitting stresses induced by the expansive nature of corrosion products, the further ingress of aggressive agents is thereby controlled [23, 24, 25]. A substantial part of these investigations, however, have only been focused on the corrosion rate and have used impressed current to promote corrosion, thus disregarding the initiation period. Investigations reporting results on the period to corrosion onset of fibre reinforced concrete have, on the other hand, mainly been based on observations for uncracked specimens [25, 26, 27, 28, 29, 30]. Data for cracked concrete specimens are very scarce. Sappakittipakorn and Banthia [31] studied the corrosion process of steel bars embedded in concrete beams, reinforced with polypropylene and cellulose fibres, which were subjected to sustained loading. They reported a beneficial effect of the fibres provided the load did not exceed a certain limit, which was in agreement with the results reported by Ostertag and Blunt [32]. They subjected reinforced concrete beam specimens made with plain and hybrid fibre reinforced concrete (HyFRC) to five loading cycles and found that corrosion was delayed for fibre reinforced specimens. However, while all the plain concrete specimens presented macro-cracking, the fibre fraction of $1.5 \%$ vol. used for the HyFRC mix prevented surface cracking on the fibre reinforced concrete specimens. Niş et al. [33] studied different loading conditions, namely uncracked, statically loaded and dynamically loaded, and found that fibres showed a significant improvement only for dynamically loaded conditions.

This paper presents some of the results from an ongoing investigation aimed at determining how the corrosion process of reinforcing steel bars embedded in concrete is influenced by the addition of fibre reinforcement. In particular, the onset of corrosion initiation in concrete mixes with different types of fibres and varying loading conditions are reported and the factors influencing the corrosion initiation period of rebars are discussed. In addition, the fracture properties, the resistivity and the chloride migration coefficient for the different mixes were assessed and compared through material testing.

\section{Experimental Programme}

The experimental programme presented in this study was designed to investigate the influence of fibre reinforcement on chloride-induced corrosion of conventional rebar for sound and cracked specimens subjected to different load conditions.

The central part of the experimental investigation comprises 54 beam specimens, six of which were used as reference samples. The other specimens were divided into several groups and subjected to different loading conditions (see Table 1). The loading cases considered included: (1) Uncracked series: sound specimens, which were never loaded; (2) Unloaded series: cracked specimens which were loaded once and then kept unloaded; (3)Cyclic series: cyclically loaded specimens, which were subjected to five load cycles and then kept unloaded, with the intention of causing a higher interfacial damage than (2); and, finally, (4)Loaded series: loaded specimens, which were preloaded to induce cracking and then kept loaded with a constant and sustained load, using steel brackets and a hinge.

In an attempt to attain realistic results, natural corrosion through the exposure to a highly con- 
Table 1: Experimental Programme

Stored in fresh water

\begin{tabular}{|c|c|c|c|}
\hline $\begin{array}{c}\text { Load } \\
\text { conditions }\end{array}$ & Series $^{\text {a) }}$ & $\begin{array}{c}\text { Target } \\
\text { crack widths }\end{array}$ & Quantity \\
\hline uncracked & PL & - & 3 \\
& ST & - & 3 \\
\hline
\end{tabular}

Cyclic exposure to chloride solution

\begin{tabular}{|c|c|c|c|c|c|}
\hline \multicolumn{3}{|c|}{$\begin{array}{c}\text { Load } \\
\text { conditions }\end{array}$} & Series $^{\text {a) }}$ & $\begin{array}{c}\text { Target } \\
\text { crack widths }\end{array}$ & Quantity \\
\hline \multirow{3}{*}{\multicolumn{3}{|c|}{ uncracked }} & PL & - & 3 \\
\hline & & & $\mathrm{ST}$ & - & 3 \\
\hline & & & HY & - & 3 \\
\hline \multirow{9}{*}{ 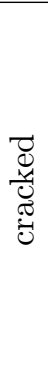 } & \multirow{7}{*}{ 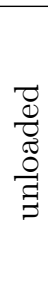 } & & $\mathrm{PL}$ & $0.1,0.2,0.3,0.4$ & 4 \\
\hline & & 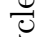 & ST & $0.1,0.2,0.3,0.4$ & 4 \\
\hline & & bे & HY & $0.1,0.2,0.3,0.4$ & 4 \\
\hline & & & SY & $0.1,0.2,0.3,0.4$ & 4 \\
\hline & & 0 & $\mathrm{PL}$ & $0.1,0.2,0.3,0.4$ & 4 \\
\hline & & : & $\mathrm{ST}$ & $0.1,0.2,0.3,0.4$ & 4 \\
\hline & & 20 & HY & $0.1,0.2,0.3,0.4$ & 4 \\
\hline & \multirow{2}{*}{\multicolumn{2}{|c|}{ loaded }} & $\mathrm{PL}$ & $0.1,0.2,0.3,0.4$ & 4 \\
\hline & & & $\mathrm{ST}$ & $0.1,0.2,0.3,0.4$ & 4 \\
\hline
\end{tabular}

a) $\mathrm{PL}=$ plain $\mathrm{ST}=$ steel $\mathrm{HY}=$ hybrid $\mathrm{SY}=$ synthetic

centrated salt solution was chosen as the method to trigger corrosion initiation. Half-cell potential measurements were continuously monitored to determine the corrosion onset.

\subsection{Specimen design and materials}

The geometry of the specimens employed in the present investigation are illustrated in Fig. 1. The beams featured total dimensions of $100 \times 180 \times$ $1100 \mathrm{~mm}$ and were reinforced with three $\varnothing 10$ ribbed bars. The reinforcement was positioned to obtain a clear concrete cover of $30 \mathrm{~mm}$ at the bottom and sides of the beam whereas the distance between bars was kept at $45 \mathrm{~mm}$, slightly more than the size of the longest fibre type. Longitudinally, the reinforcement bars also had a concrete cover of $30 \mathrm{~mm}$ at one of the ends whereas they stuck out about $50 \mathrm{~mm}$ at the other end to allow electrical connections.

The same concrete mix, apart from the addition of fibres, was used for all series in this project. Table 2 summarizes the concrete mix proportions. The concrete was designed with a $w / c$ ratio of 0.47 and was chosen to be a self-compacting mix to guarantee a good flowability of the concrete despite the addition of fibres. As reinforcement, a grade B500B steel defined in Eurocode 2 as possessing normal ductility, was used. The average values of the yield stress, the tensile strength and the maximum strain, obtained through tensile tests performed on $450 \mathrm{~mm}$ long bars, were $f_{y}=546 \mathrm{MPa}, f_{u}=626 \mathrm{MPa}$ and $\varepsilon_{u}=9,76 \%$, respectively. Steel bars were used as received, i.e., without applying any surface treatment to them prior to casting.

Four different series of specimens, hereafter referred to as plain, steel, synthetic and hybrid, were cast using embedded conventional reinforcement. The series differed by the type of fibre reinforcement used: none for the plain series; 35 $\mathrm{mm}$ end-hooked steel fibres for the steel series; 30 mm straight PolyVinyl Alcohol (PVA) fibres for the synthetic series; and a blend of the steel fibres mentioned and $18 \mathrm{~mm}$ long PVA fibres for the hybrid series. The fibre characteristics have been summarized in Table 3 .

In addition to the beam specimens already described, a series of companion specimens were simultaneously cast for material characterization of the different concrete mixes. These companion specimens included: $150 \mathrm{~mm}$ sided cubes for compressive strength tests; $100 \mathrm{~mm}$ diameter cylinders to determine the resistivity and chloride migration coefficient of the concrete; and $150 \times 150 \times 550 \mathrm{~mm}$ beams to evaluate the fracture mechanical properties of the fibre-reinforced mixes according to EN 14651 [34].

\subsection{Casting and curing}

During casting of the beam specimens, in order to guarantee the correct positioning of the rebars, fibre-reinforced concrete spacers from MaxFrank ${ }^{\circledR}$ were used. The spacers, designed with a highdensity concrete and low chloride diffusion coefficient $\left(<5.0 \cdot 10^{-12} \mathrm{~m}^{2} / \mathrm{s}\right)$, had a nominal height of $60 \mathrm{~mm}$ to permit positioning them alongside the larger concrete cover to hinder the ingress of chlorides through the interface between the spacers and the cement paste. The beams were cast with the bars hanging from the spacers, as shown in Fig. 2, a choice made while bearing in mind that smaller cover layers produce smaller concrete settlements under the reinforcement, thus minimizing the potential interfacial defects along the rebar. Moreover, this setup of the spacers 


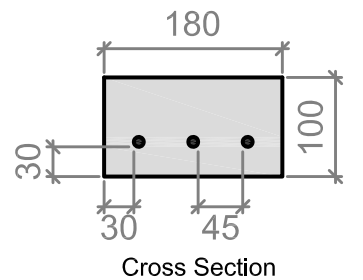

Cross Section

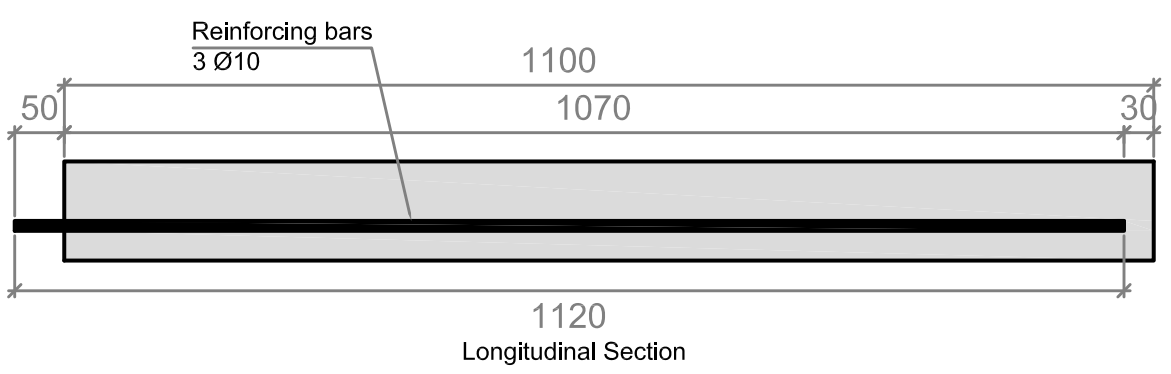

Figure 1: Specimen geometry. (Measurements in $\mathrm{mm}$ )

Table 2: Mixture proportions, in $\mathrm{kg} / \mathrm{m}^{3}$

\begin{tabular}{|c|c|c|c|c|}
\hline Component & & & & \\
\hline Cement (CEM I 42.5N SR 3 MH/LA) & & & 360 & \\
\hline Limestone filler (Limus 40) & & & 165 & \\
\hline Fine aggregate (sand $0 / 4)$ & & & 770 & \\
\hline Coarse aggregate (crushed 5/16) & & & 833 & \\
\hline Effective water & & & 169 & \\
\hline Superplasticizer - Glenium 51/18 & & & 5.76 & \\
\hline Air entrainer - MicroAir 105 & & & 0.72 & \\
\hline Fibre (vol.\%) & Plain & Steel & Hybrid & Synthetic \\
\hline Steel - Dramix ${ }^{\circledR} 65 / 35-\mathrm{BN}$ & - & 0.5 & 0.35 & - \\
\hline PVA - Kuralon ${ }^{\mathrm{TM}}$ RFS400 & - & - & 0.15 & - \\
\hline PVA - Kuralon ${ }^{\mathrm{TM}}$ RF4000 & - & - & - & 0.75 \\
\hline
\end{tabular}

avoided having fibres sticking out from the surface of the concrete on the side of the smaller concrete cover. All specimens were outfitted with a reference electrode embedded in the concrete to allow the continuous monitoring of corrosion potential (see Fig. 2).

The beam specimens were cast in plywood formwork and covered with a polyethylene sheet for 24 hours. After that, the formwork was removed and the beams wetted and wrapped in geotextile and plastic sheets. Thereafter, all the specimens were stored (in the wrapping) at room temperature until they were preloaded for a period ranging from 72 to 82 days.

\subsection{Material tests}

In order to compare the material properties and mechanical performance of the different concrete mixes used in the present investigation, a series of material tests were performed.

\subsubsection{Compressive Strength}

The Compressive strength of each concrete mix was determined by using three cubic specimens with a side length of $150 \mathrm{~mm}$. The specimens were cured in water according to EN 12390-2 [35] and were tested under monotonic load after a period of 28 days according to EN 12390-3 [36].

\subsubsection{Rapid Chloride Migration test}

The chloride migration coefficient for the different mixes was obtained through non-steadystate migration experiments in accordance with NT-Build 492 [37. Cylindrical specimens with $\varnothing 100 \times 200 \mathrm{~mm}$ dimensions were cast and three discs of $50 \mathrm{~mm}$ thickness were cut from the central part. Prior to testing the specimens had been water cured for a period of seven weeks.

\subsubsection{Resistivity test}

The electrical resistivity of concrete was assessed using a uniaxial electrode configuration. The specimens employed were the same that were later used to determine the chloride migration coefficient. After 24 hours of immersion in $\mathrm{Ca}(\mathrm{OH})_{2}$ saturated solution, the cut cylinders were placed between two plate-shaped electrodes using wet sponges to ensure good electrical contact. In these tests, a constant alternating current (AC) at $1 \mathrm{kHz}$ was applied and the resistance between the two electrodes measured using a LRC meter. The resistivity was determined applying a geometric fac- 
Table 3: Fibre reinforcement properties

\begin{tabular}{lccc}
\hline & $\begin{array}{c}\text { Dramix } \\
\text { Property }\end{array}$ & $\begin{array}{c}\text { Kuralon }^{\text {TM }} \\
\text { R5/35-BN }\end{array}$ & $\begin{array}{c}\text { Kuralon }^{\text {TM }} \\
\text { RFS400 }\end{array}$ \\
RF4000 \\
\hline Material & Low carbon & Polyvinyl & Polyvinyl \\
& steel & Alcohol & Alcohol \\
Length $[\mathrm{mm}]$ & 35 & 18 & 30 \\
Diameter $[\mu \mathrm{m}]$ & 550 & 200 & 660 \\
Aspect ratio & 65 & 90 & 45 \\
Shape & End-hooked & Straight & Straight \\
Tensile Strength $[\mathrm{MPa}]$ & 1100 & 1000 & 800 \\
Young's Modulus $[\mathrm{GPa}]$ & 210 & 30 & 29 \\
\hline
\end{tabular}

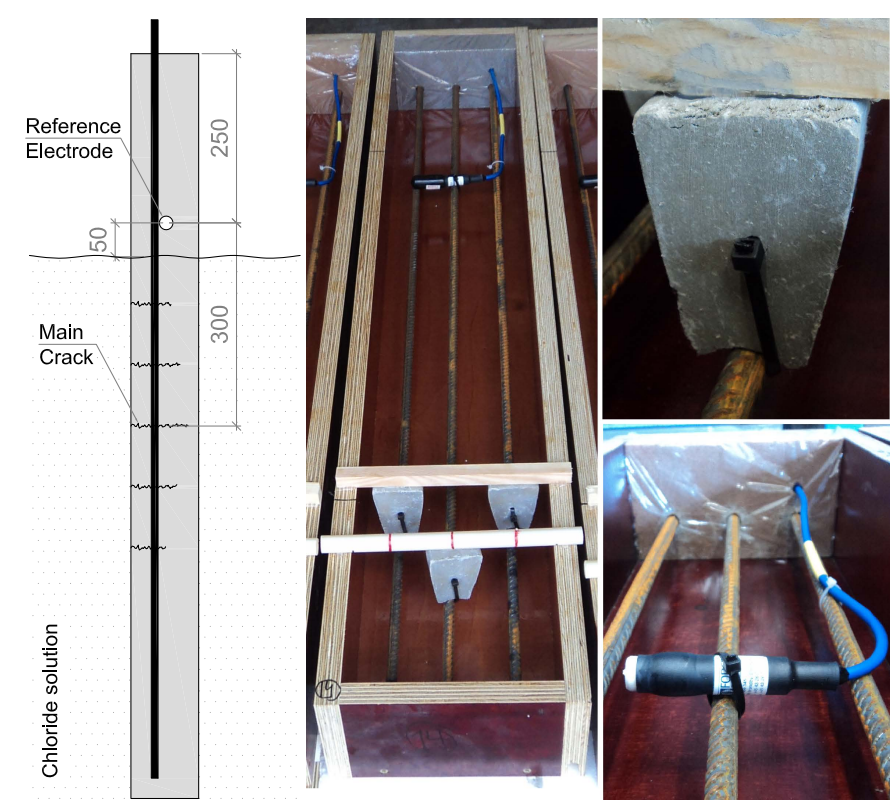

Figure 2: Relative position of the reference electrode, in mm (left), general view of the formworks (centre), detail of a fibre-reinforced concrete spacer (right-top) and an embeddable reference electrode (right-bottom)

tor, $k=A / l$, where $A$ and $l$ represent the cross section and thickness of the discs, respectively.

\subsection{Corrosion experiments}

\subsubsection{Pre-loading procedure}

A three-point loading configuration, as shown in Fig. 3, was used to introduce a desired bending moment to the beam specimens. The distance between the end supports was $1000 \mathrm{~mm}$, and the load was applied at the mid-span. Loading was performed with a double-effect hydraulic jack with a maximum load capacity of $100 \mathrm{kN}$. Four linear variable displacement transducers (LVDTs) were placed on the concrete beam, two at the midspan section at either side of the loading plate, and an additional LVDT at each end-support section.

Loading was performed by displacement control at a displacement rate of $0.1 \mathrm{~mm} / \mathrm{min}$, whereas for the cyclic loaded specimens (subjected to five loading cycles), the displacement rate was $1 \mathrm{~mm} / \mathrm{min}$. During the loading procedure, the crack width opening of the widest crack formed in each specimen was measured using a crack detection microscope with a magnification of $20 \times$ and an accuracy of $0.02 \mathrm{~mm}$. Table 4 shows the maximum applied loads during the pre-loading procedure for all cracked beam specimens. The target crack width openings were $0.1,0.2,0.3$ and 0.4 $\mathrm{mm}$. Upon unloading, the remaining crack width openings generally ranged between $0.02 \mathrm{~mm}$ and $0.06 \mathrm{~mm}$.

Table 4: Maximum applied load during pre-loading procedure for cracked beam specimens, in $\mathrm{kN}$.

\begin{tabular}{llcccc}
\hline \multirow{7}{*}{ Plain } & & Target crack width $[\mathrm{mm}]$ \\
& & 0.1 & 0.2 & 0.3 & 0.4 \\
\hline \multirow{3}{*}{ Steel } & Unloaded & 12.4 & 18.5 & 21.5 & 27.5 \\
& Loaded & 11.5 & 14.7 & 27.0 & 27.5 \\
& Cyclic & 14.0 & 17.0 & 24.6 & 25.1 \\
\hline \multirow{2}{*}{ Hybrid } & Unloaded & 14.0 & 21.2 & 28.6 & 34.8 \\
& Loaded & 16.8 & 21.5 & 29.0 & 33.0 \\
& Cyclic & 13.0 & 24.2 & 25.6 & 34.0 \\
\hline \multirow{2}{*}{ Synthetic } & Unloaded & 13.0 & 18.3 & 26.3 & 33.6 \\
& Cyclic & 13.8 & 22.0 & 27.0 & 33.0 \\
\hline
\end{tabular}

\subsubsection{Sustained loading set-up}

A sustained load was applied to eight of the specimens using a similar setup as the one described by Jaffer and Hansson [38]. The beams selected, belonging to the plain and steel series, were coupled into pairs according to the crack 

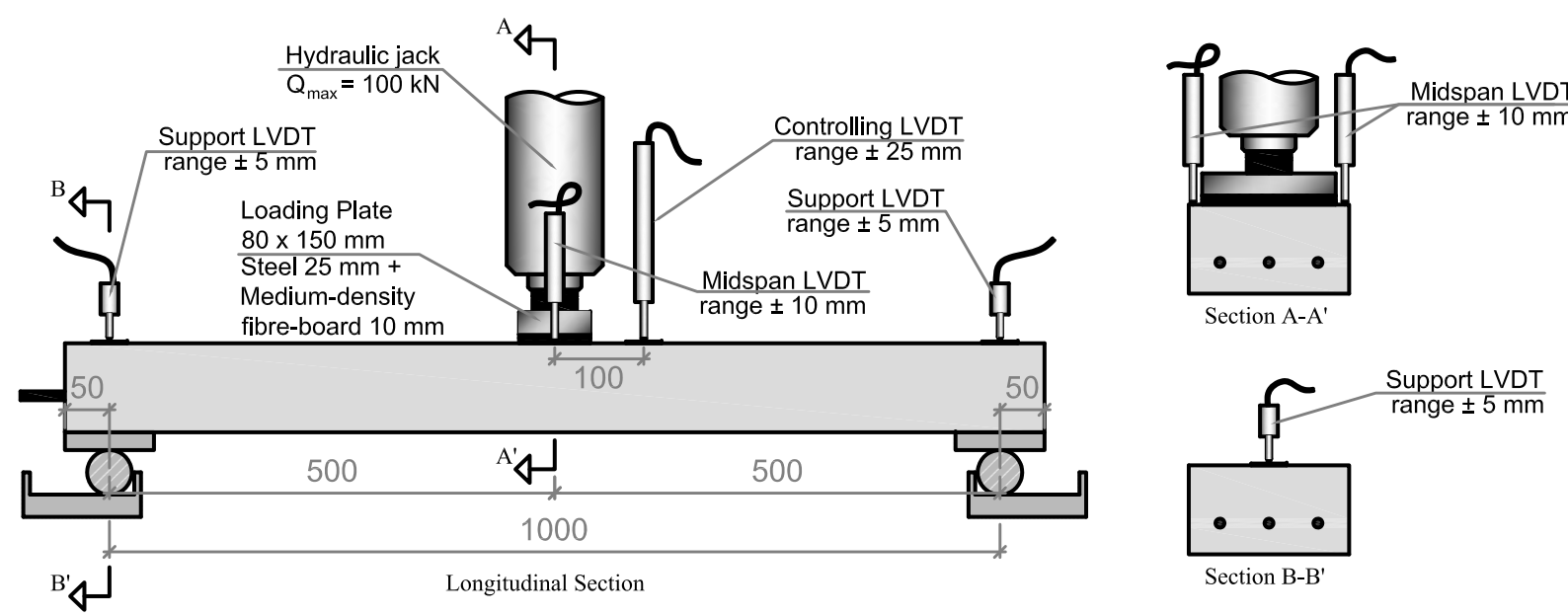

Figure 3: Three point bending setup used during the pre-loading procedure to induce bending cracks. (Measurements in mm)

width opening aimed during the pre-loading procedure. Stainless steel brackets, consisting of two hollow rollers clamped to the concrete beams using threaded rods and nuts, were installed on the coupled beams about 22 weeks after casting. The specimens were subjected to three-point bending using the set-up illustrated in Fig. 4.

The load was introduced by tightening the nuts on the threaded rods. Additionally, strain gauges were placed on the threaded rods of every upper bracket and were calibrated before the beams had been loaded. This was accomplished to accurately measure the load applied during the loading procedure, as well as to keep track of the load losses due to creep and relaxation in order to compensate for them. The beams from the plain series were coupled with the beams in the steel series according to target crack width. Since the load applied during the pre-loading procedure had varied for beams belonging to different series, the coupled beams were loaded to an average value as shown in Table 5. Consequently, the crack widths for the coupled beams were expected to deviate slightly from target crack widths.

\subsubsection{Exposure conditions}

After curing and pre-loading, all specimens were kept in laboratory environmental conditions. Before exposing the specimens to chlorides, they were placed standing vertically into plastic tanks and left to soak in potable water during two weeks to ensure that they were saturated prior to chloride exposure. During that period, the $16.5 \%$
Table 5: Applied loads during pre-loading procedure and intended loads for sustained loads, in $\mathrm{kN}$.

\begin{tabular}{lcccc}
\hline & \multicolumn{3}{c}{ Target crack width $[\mathrm{mm}]$} \\
& 0.1 & 0.2 & 0.3 & 0.4 \\
\hline $\begin{array}{l}\text { Plain series } \\
\text { Max. load reached }\end{array}$ & & & & \\
during pre-loading & 11.5 & 14.7 & 27.0 & 27.5 \\
\hline $\begin{array}{l}\text { Steel series } \\
\text { Max. load reached } \\
\text { during pre-loading }\end{array}$ & 16.8 & 21.5 & 29.0 & 33.0 \\
\hline $\begin{array}{l}\text { Intended load } \\
\text { for coupled beams }\end{array}$ & 14.2 & 18.1 & 28.0 & 30.3 \\
\hline
\end{tabular}

$\mathrm{NaCl}$ solution (corresponding to a $10 \% \mathrm{Cl}^{-}$concentration) was prepared in different tanks. The exposure of the beams to the chloride solution was performed by partial immersion, setting the water level to submerge $75 \%$ of the beam length. The exposure of the beams to chlorides was performed progressively according to their loading conditions; thus, the age of the specimens at the initiation of the exposure was: 18 weeks for the uncracked beams; 20 weeks for the unloaded and cyclically loaded beams; and 22 weeks for the loaded beams.

Immersion was performed cyclically to hasten the corrosion process and to correspond to the XS 3 or XD 3 exposure class in EN 206 [39]. The cyclic periods consisted of two weeks of wetting, during which the tanks were covered with plastic sheets to prevent evaporation of water, followed by two weeks of drying at laboratory conditions $\left(20.5 \pm 3.6^{\circ} \mathrm{C}\right.$ and $\left.45 \pm 15 \% \mathrm{RH}\right)$. 


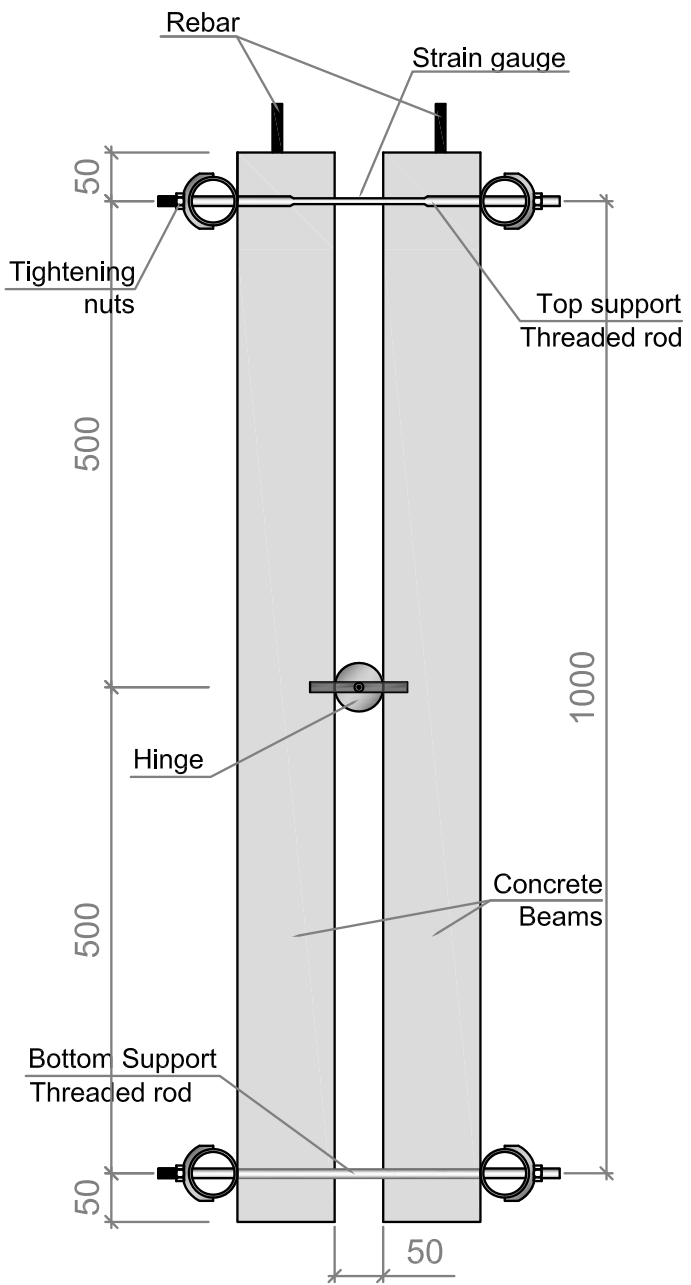

Figure 4: Setup for sustained loading. (Measurements in $\mathrm{mm}$ )

\subsubsection{Half-Cell Potential (HCP) monitoring}

The phenomenon of corrosion is an electrochemical process which can be understood as two halfcell reactions, the anodic and the cathodic reactions, taking place between the metal surface and the environment with which it is in contact. Both of these reactions happen simultaneously and are necessary for the continuance of the corrosion process.

$\mathrm{HCP}$ is an indicator of the thermodynamic state of a metallic surface, which is measured as the potential difference (voltage) between the metal surface and a reference electrode. Commonly used reference electrodes include Saturated Calomel Electrode (SCE), Silver/Silver Chloride Electrode (SSC) or Copper/Copper Sulfate Electrode (CSE) 40]. Table 6 provides an interpretation of half-cell potential values for the assessment of the corrosion state of steel embedded in chloride-contaminated concrete, according to ASTM C876-09 [41].

In this investigation, the ERE 20 (Embeddable Reference Electrode) from FORCE Technology was used. The ERE 20 reference electrode is a true reference electrode based on the reaction between $\mathrm{MnO}_{2}$ and $\mathrm{Mn}_{2} \mathrm{O}_{3}$ in a very alkaline electrolyte $(\mathrm{pH}=13.5)$. The solution is placed in a stainless steel case to provide electrical contact and the electrode is equipped with an ionmembrane of cement mortar at the tip to ensure good affinity with concrete. Fig. 5 shows the ERE 20 reference electrode components. Embeddable electrodes offer the advantage that they can be placed relatively close to the reinforcement, thus reducing errors related to the resistivity of the concrete. Embeddable electrodes, unlike the portable ones, can however only measure the corrosion potential in the vicinity of the electrode location.

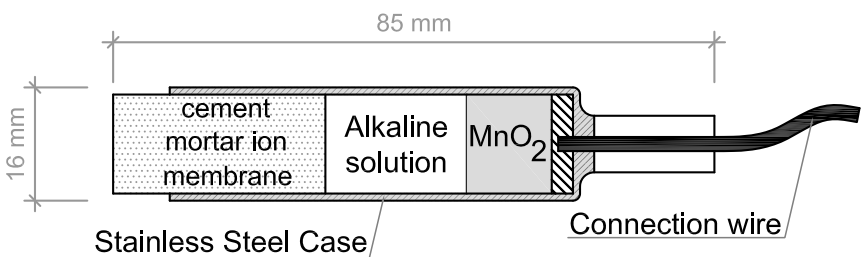

Figure 5: ERE20 - cross section.

In cracked concrete, the expected corrosion mechanism is macro-cell corrosion with the areas of steel crossing the cracks acting as anodes [9, 38]. Corrosion potential can, therefore, vary significantly along the rebar depending on the distance to the anode and the moisture conditions of concrete, as illustrated in Fig. 6. This parameter must be considered when interpreting the measurements of corrosion potential.

\section{Results and discussion}

\subsection{Material tests}

The results from the material tests of the different concrete mixes are shown in Fig. 7 and Fig. 8. As observed, the addition of fibres in low dosages had a marginal effect on the compressive strength of concrete. Similarly, fibres did not significantly affect the flexural strength of concrete while the post-peak flexural behaviour was greatly 
Table 6: Criteria for interpretation of half-cell potential, according to ASTM C876-09 41]

\begin{tabular}{c|l}
\hline $\mathrm{Cu} / \mathrm{CuSO}_{4}$ electrode & Likely corrosion condition \\
\hline$>-200 \mathrm{mV}$ & Low $(10 \%$ risk of corrosion $)$ \\
-200 to $-350 \mathrm{mV}$ & Intermediate corrosion risk \\
$<-350 \mathrm{mV}$ & High $(>90 \%$ corrosion risk $)$ \\
\hline
\end{tabular}

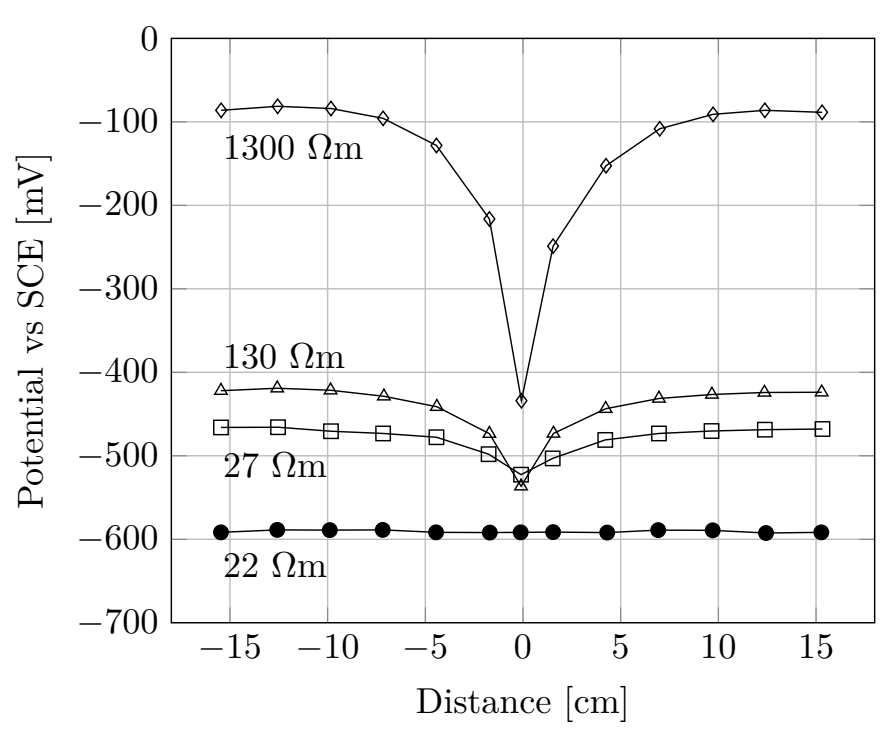

Figure 6: Influence of resistivity of concrete and distance to the anode on the measurements of HCP, 42.

enhanced in terms of toughness. Among the three fibre reinforced concrete series, the addition of $0.5 \%$ vol. steel fibres resulted in the greatest improvement whereas $0.75 \%$ vol. PVA macro fibres showed the lowest toughness.

No major variation in the chloride migration coefficient for the different mixes was observed. These results are in agreement with those of Teruzzi et al. [22] who concluded that the interfacial zone between the fibres and the cement paste does not act as a preferential path for the ingress of detrimental agents. The microstructure of the interfacial transition zone (ITZ) of macro-fibres, those with a diameter over $0.1 \mathrm{~mm}$, has been found to be similar to that observed around aggregates [43, 44, i.e., a zone presenting a higher porosity compared to the bulk matrix. Even though the amount of additional surface and, consequently, ITZ volume provided by the fibres is not negligible compared to that provided by the coarse aggregate fraction, the results do not indicate a significant impact on the ingress of chlorides caused by the addition of fibres. It is also noteworthy that the use of a self-compacting concrete helped to offset the reduction in workability sometimes associated with fibre concrete which might result in an increase of entrapped-air voids and the consequent increase in permeability.

Resistivity measurements, on the other hand, revealed a clear influence of fibres on this property. In saturated conditions, resistivity of concrete containing steel fibres was considerably reduced, a reduction that seemed to be proportional to the fibre content. Furthermore, despite the high resistivity of PVA macro-fibres, the synthetic series also showed a decrease in resistivity compared to plain concrete specimens. Similar results regarding the electrical resistivity of steel and PVA fibre concrete were reported by Kim and Lee in [45], who highlighted that resistivity measurements might not necessarily be a good indicator of chloride ion permeability, especially in the case of conductive fibres.

\subsection{HCP Measurements}

The corrosion potential of passivated steel in moist, chloride-free concrete usually range between +100 and $-200 \mathrm{mV}$ [42. For concrete exposed to chlorides, corrosion initiation is commonly followed by a sudden drop in the half-cell potential. A selection of the HCP monitored in this investigation is shown in Fig. 9, where the shaded areas represent the wetting periods. While specimens belonging to the unloaded and cyclically loaded series needed days or weeks to show a drop in potential, it only took a few hours to register this change for all the specimens in the series with sustained load regardless of the addition of fibres. This fact highlights the importance of the loading state of the structure (loaded vs unloaded) for the initiation period of corrosion.

\subsubsection{Influence of concrete resistivity and distance to the anode}

As already mentioned in Section 2.4.4, the resistivity of concrete and the distance to the anode 


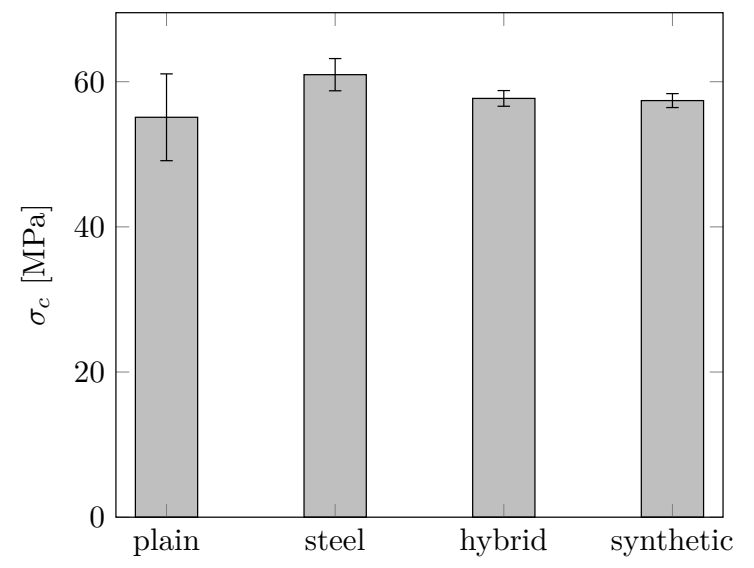

(a) Compressive Strength

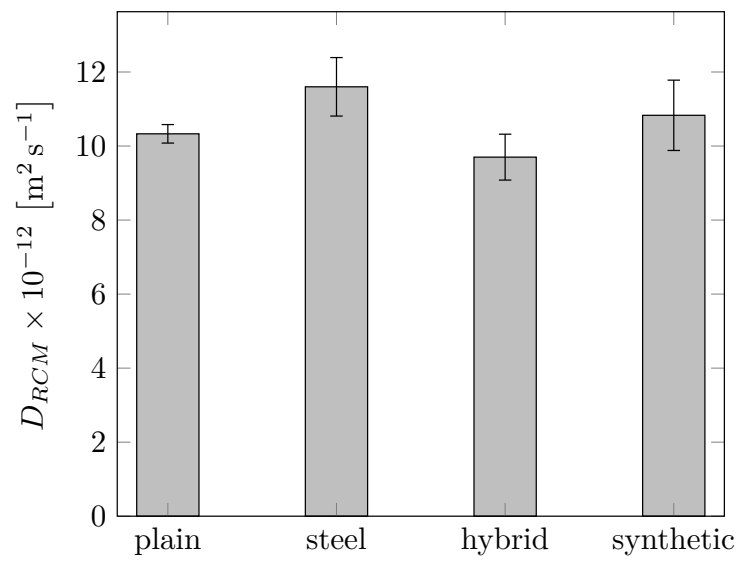

(b) Chloride Migration

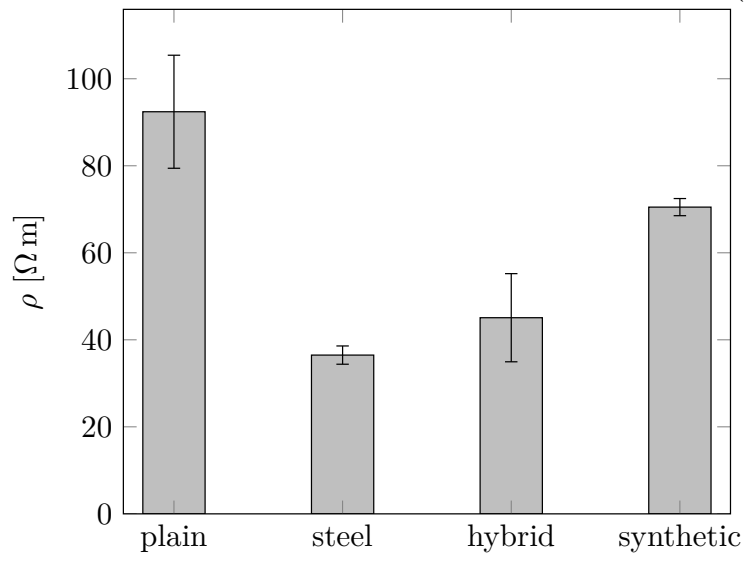

(c) Resistivity

Figure 7: Results of material characterization for the different concrete mixes (mean values and standard deviation for three specimens)

are parameters that greatly influence the potential readings and, therefore, they must be taken into account when interpreting half-cell potential measurements. Fig. 10 shows the average electrical resistivity of the concrete cover at the reference electrode location for the different concrete mixes measured over a period of time ranging between 12 and 22 weeks with a handheld device named RapiCor [46]. It can be observed that the mean values are markedly higher and the variations between the different mixes are significantly lower than in the resistivity tests shown in Fig. 7. This effect might be attributed to a combination of factors: at this location, concrete is never immersed and, therefore, the concrete cover will not be completely saturated, indicating the major influence of the moisture content on resistivity. Moreover, a two-dimensional orientation of fibres at the cover of the beam specimens, perpendic- ular to the current flow, as opposed to a more one-dimensional orientation of the fibres, parallel to the current flow in the cylinder specimens, may have also influenced the resistivity measurements. Nevertheless, in comparing these results with the curves shown in Fig. 6 it may be expected that corrosion potential will be 100 to $150 \mathrm{mV}$ higher at a distance of between 5 and $15 \mathrm{~cm}$ from the anode. Even though the position of the anode cannot be precisely determined for the beam specimens upon corrosion initiation, given the dimensions of the beams and the location of the embedded electrode at $30 \mathrm{~cm}$ from the midspan, the anode will most likely be at a distance of about $30 \mathrm{~cm}$ from the reference electrode. Further, it must be noted that sudden drops in potential, as observed in this experiment, usually fall below $-200 \mathrm{mV}$ but do not always reach a value of $-350 \mathrm{mV}$ (see Fig. 9). Based on this fact, the values presented 


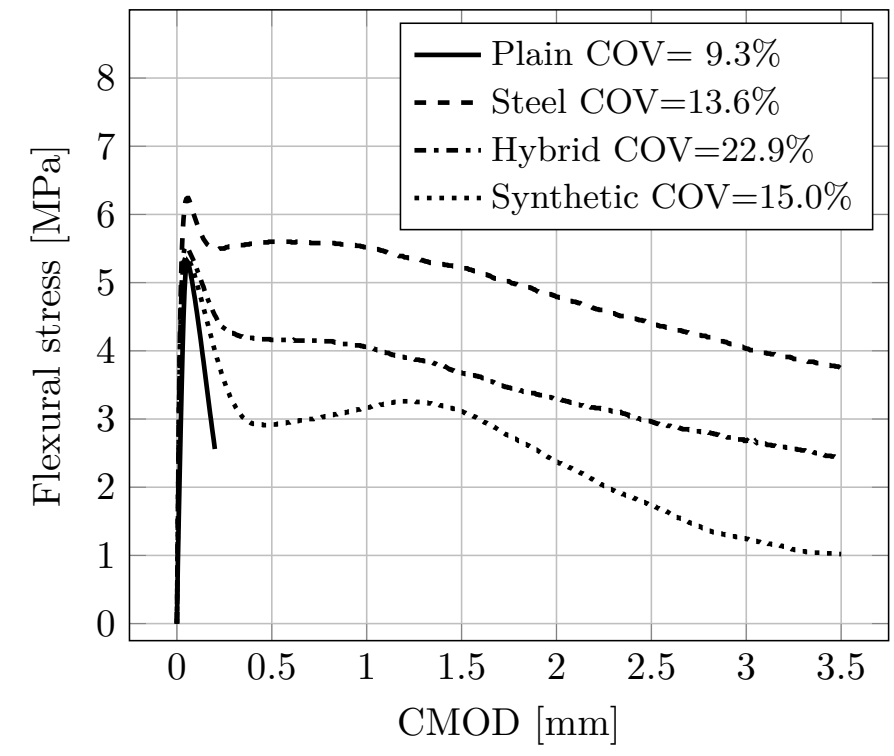

Figure 8: Load-deflection curves for three-point bending tests (mean values for six specimens)

in Table 6, which only represent the probability of corrosion risk, need to be adjusted to avoid misleading results. Therefore, in this investigation, the criteria used to define the point in time when corrosion initiates was based on the suggestion by RILEM TC-235 CTC "Corrosion Initiating Chloride Threshold Concentrations in Concrete", i.e., a sudden drop in hall-cell potential by more than $150 \mathrm{mV}$ per $24 \mathrm{~h}$ and no re-passivation occurring in the following seven days.

\subsubsection{Influence of fibre reinforcement}

The mean values of the initial half-cell potential for the different concrete mixes and loading conditions, averaged over the specimens with varying crack width, are plotted in Fig. 11. Except for the steel series in the Loaded case, it can be observed that, the rest of the specimens with fibre reinforcement consistently showed higher initial HCP than plain concrete specimens. Although in other investigations fibres did not seem to affect the initial HCP [30, 32], in the literature, reported results of HCP measurements exist where this effect can be also observed [17, 33]. These results may be explained by fibres interfering with the oxygen availability around the steel-concrete interface, by possibly supplying additional oxygen through the relatively weak fibre-concrete interfaces, resulting in higher initial HCP values. However, as previously mentioned, fibres do not seem to act as preferential paths for external agents and according to the findings by Teruzzi et al. [22] that is also applicable to oxygen permeability. Thus, the phenomenon causing this effect and the impact on the HCP measurements under active corrosion conditions are unclear and require further research. Therefore, in the present investigation, this effect has not been considered for determining the corrosion initiation times.

\subsection{Corrosion initiation time}

The major impact of cracks on concrete durability is highlighted in this study by the fact that after a period of 120 days from the first exposure to chloride solution, all cracked specimens had started to corrode while none of the uncracked specimens showed any corrosion signs even after 180 days of cyclic exposure. This means, however, that no information is yet available about the initiation times for uncracked specimens, hence only results from cracked specimens have been here discussed. The corrosion initiation times for the different concrete mixes, as a function of the maximum crack width reached during the pre-loading procedure (or measured crack width under sustained loading for the Loaded series) are presented in Fig. 12. The initiation times were determined from the half-cell potential measurements based on the criteria described in Section 3.2.1.

\subsubsection{Influence of crack width}

Overall, the corrosion initiation times showed a tendency to decrease with increasing crack width, except for the Loaded beams, where reinforcement corrosion was initiated shortly after starting the first cycle of immersion in a chloride solution (see. Fig. 12c). The correlation between corrosion initiation and maximum crack width attained is especially clear in the case of the plain and the steel series in Unloaded beams (see Fig. 12a) but becomes less apparent in other cases. However, after pre-cracking, the crack width of the beams belonging to the Unloaded and Cyclic series generally ranged between 0.02 and $0.06 \mathrm{~mm}$, while for the Loaded, beams the cracks were re-opened to the target values ranging between 0.1 and 0.4 mm.

This observation suggests that if the surface crack widths are about $0.1 \mathrm{~mm}$ or larger for the 


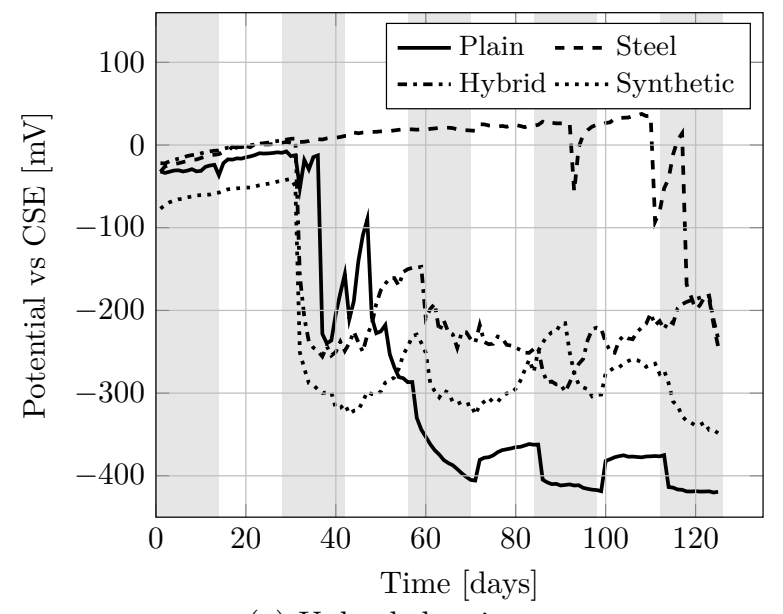

(a) Unloaded series

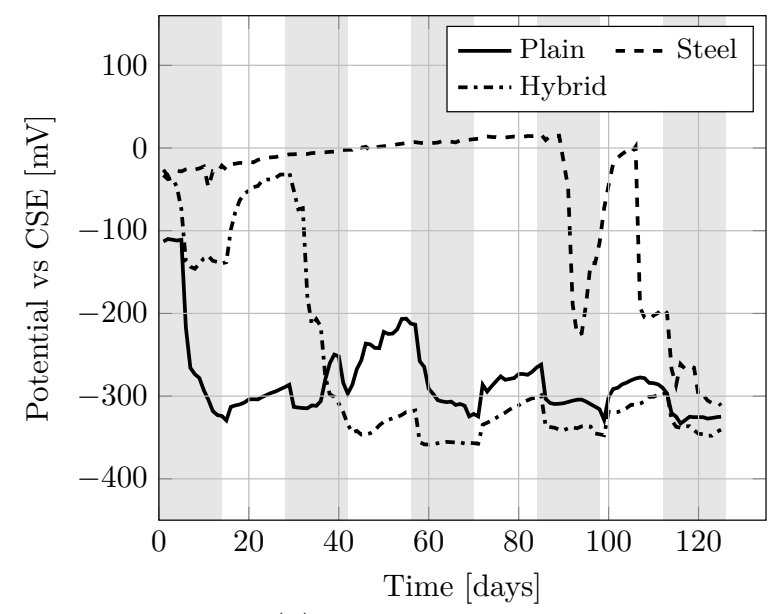

(b) Cyclic series

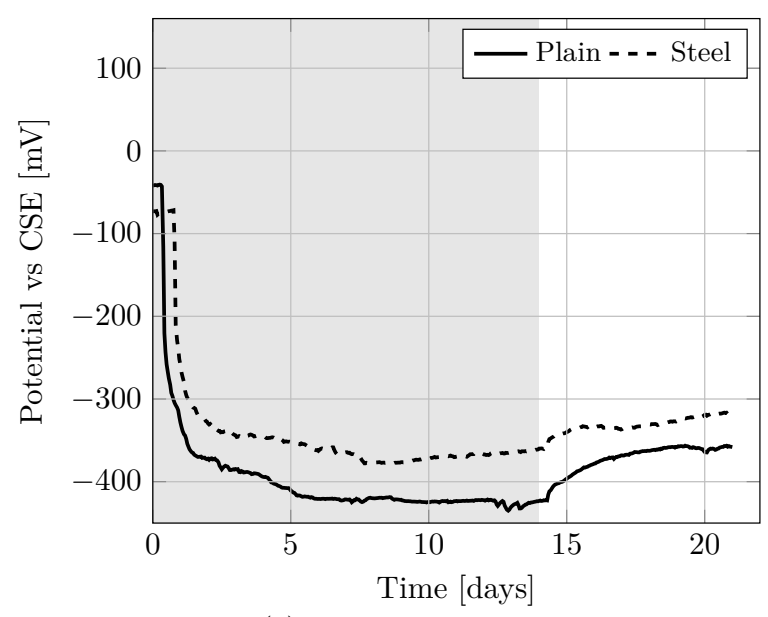

(c) Loaded series

Figure 9: Half-cell potential for cracked concrete specimens subjected to different loading conditions (central rebar; target crack width 0.1 $\mathrm{mm})$. Note the different scale used for the time axis in the Loaded series.

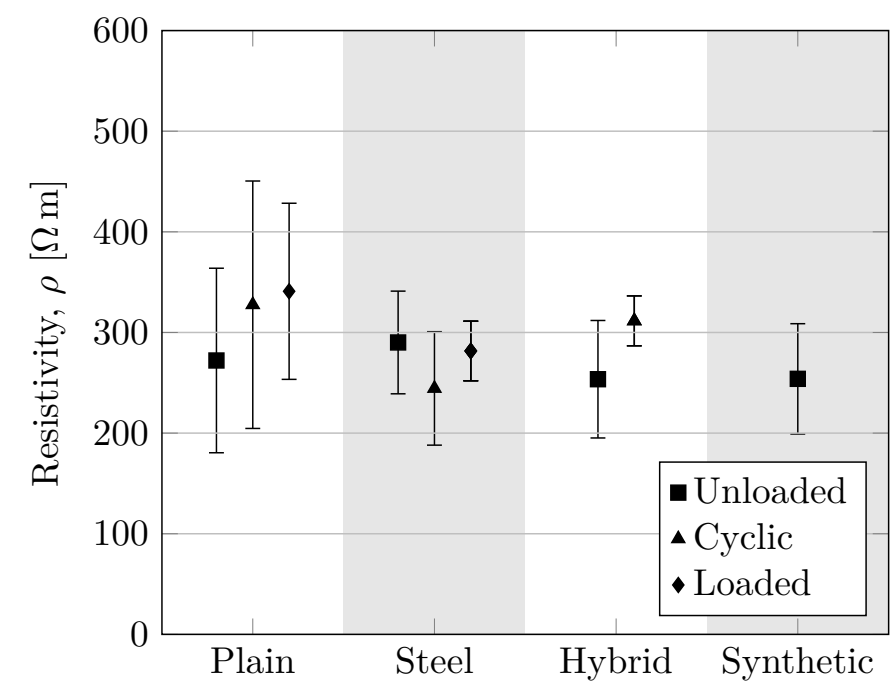

Figure 10: Resistivity of beam specimens at embedded reference electrode location conditions used in this experiment, corrosion can be initiated almost immediately after exposure to chlorides. However, as discussed elsewhere [12, 47], this crack width threshold may be dependent on the cover depth, the $w / c$ or binder type used, as well as the ambient aggressiveness. Therefore, although this observation supports the existence of a crack threshold above which the initiation period can, in practice, be disregarded, it cannot be directly extrapolated to real structures where larger cover depths and lower $w / c$ are commonly used. Nevertheless, despite differences on the crack width of only $0.04 \mathrm{~mm}$, the variation in times for corrosion initiation found in the Unloaded and Cyclic series, indicates that other factors such as the crack profile, internal micro-cracking or the condition of the concretereinforcement interface may play a more impor- 


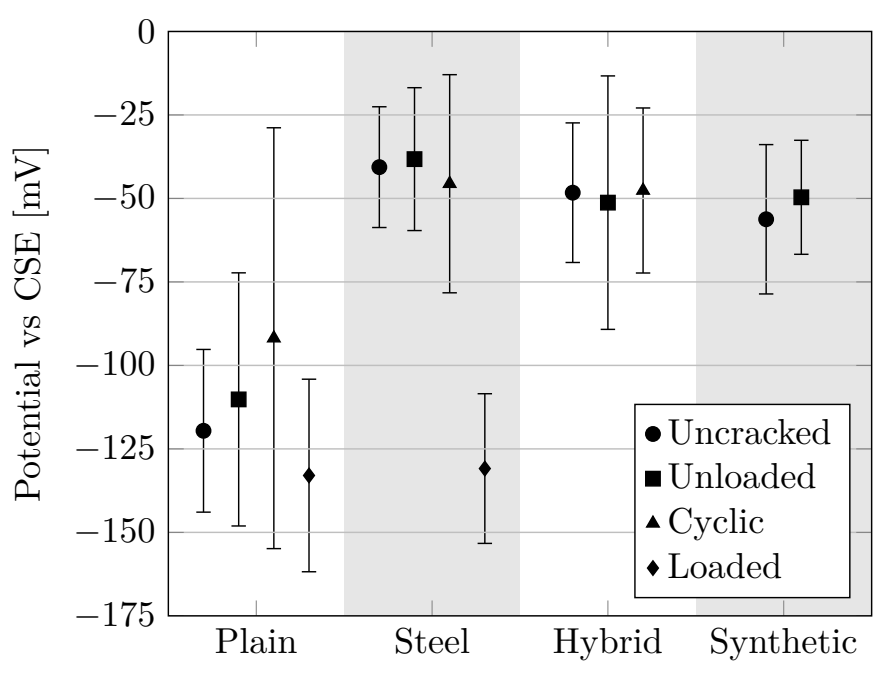

Figure 11: Initial half-cell potential for the different mixes

tant role in controlling the initiation of corrosion at the reinforcement in cracked concrete members.

\subsubsection{Influence of loading conditions and fibre type}

In Fig. 13, the corrosion initiation times have been grouped into a single chart and plotted as a function of the different series to allow graphic interpretation of the influence of the fibre type and loading conditions on corrosion initiation. The different markers represent the individual data points the size of which indicates the relative crack width (larger size, wider cracks).

Increasing the number of loading cycles from one to five seems to have a significant impact on the plain and steel series, when a certain load level has been exceeded. This fact supports the hypothesis that interfacial defects, such as air voids or debonding caused by mechanical loading, may significantly affect the initiation of corrosion. However, this behaviour was not observed for the hybrid series, indicating that if the debonding of reinforcement is a decisive factor for the initiation of corrosion, the addition of PVA micro-fibres can arrest the bond-stress crack development better than steel macro-fibres alone, thereby delaying the initiation of corrosion. Sustained load, on the other hand, influenced the corrosion onset to the extent that corrosion was initiated within a period of a few hours regardless of the crack width or the addition of steel fibres, as previously mentioned. However, the Loaded series presents two features which have been regarded in the literature as potentially harmful to the corrosion process compared to the Unloaded and Cyclic series, namely wider cracks and higher stresses on the reinforcement, which makes it impossible to discern the magnitude of each of these aspects.

Regarding the different fibre types, despite the higher elastic modulus of steel fibres, synthetic series consisting of macro PVA fibres performed better than steel series in terms of delayed corrosion onset. It can be observed in Fig. 12a that whereas corrosion initiation correlates fairly well with the maximum crack width reached for the steel series, this is not true for the synthetic series. Considering that the predominant failure mechanism of (uncorroded) steel fibres is pull-out in contrast to PVA fibres where they generally tend to break [48], it could be argued that the damage caused by the slip of the steel fibres during loading, which is greater for higher load levels, might have had a negative effect on the corrosion initiation period.

\section{Conclusions}

The influence of three different types of fibre reinforcement on the mechanical properties, chloride transport and resistivity of concrete were compared through material testing and the corrosion initiation of steel rebar was investigated for cracked beam specimens subjected to different loading conditions. The following conclusions were drawn:

1. The flexural and compressive strength of concrete were not influenced by the addition of fibre reinforcement at low dosages ( $<1 \%$ vol.) but toughness was greatly enhanced. The chloride migration coefficient seemed to remain unaffected by the presence of fibres, whereas the electrical resistivity was reduced, especially when using conductive fibres.

2. Based on half-cell potential measurements, all the cracked specimens were actively corroding after a period of 17 weeks of cyclic exposure to $16.5 \% \mathrm{NaCl}$, whereas measurements for the uncracked specimens indicated that no corrosion had started after 30 weeks of exposure. This finding means that the corrosion initiation period will be dramatically reduced for 


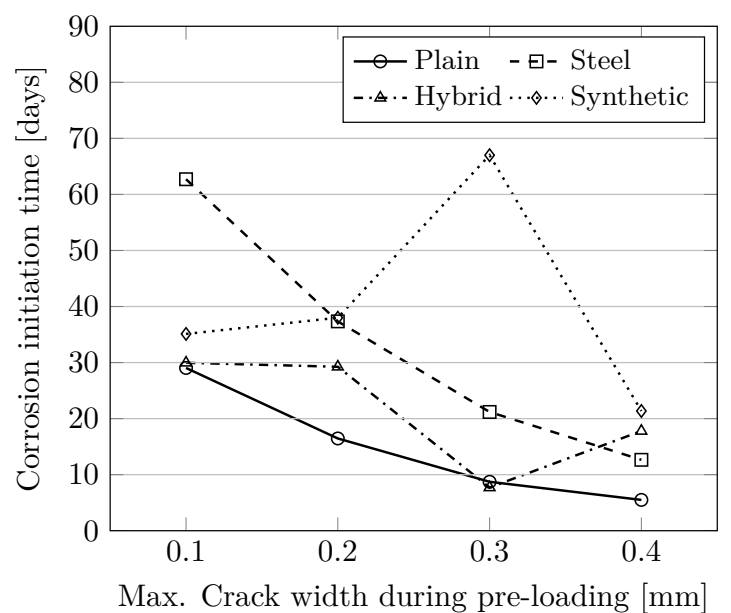

(a) Unloaded series

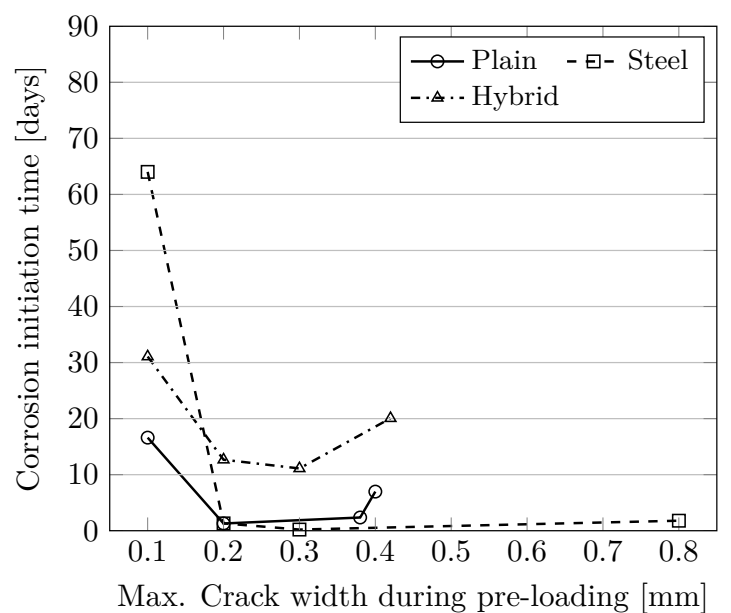

(b) Cyclic series

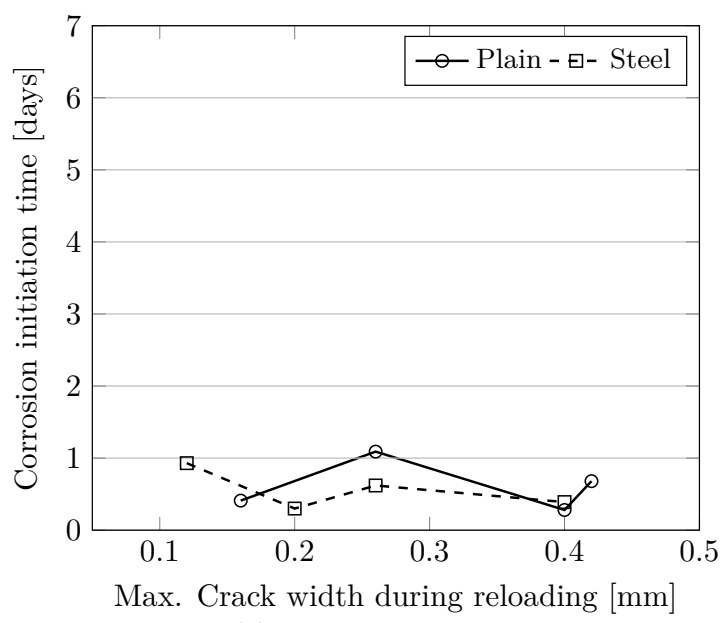

(c) Loaded series

Figure 12: Corrosion initiation times: influence of crack width. Note the different scales used for the ordinates axis in the Loaded series.

cracked concrete elements compared to sound elements, regardless of the addition of fibres to concrete.

3. For cracked concrete elements, results indicated that if the surface cracks were wider than a certain threshold, in this investigation smaller than $0.1 \mathrm{~mm}$, corrosion of the reinforcement would initiate almost immediately. This limit would, however, will be influenced by other factors, e.g. $w / c$, concrete cover or crack profile, which were not subject of assessment in this study.

4. For the Unloaded and Cyclic series, despite surface cracks ranging between 0.02 and 0.06 $\mathrm{mm}$ after removing the load, the length of time to corrosion initiation tended to be shorter for the specimens with wider induced cracks during the pre-loading procedure. This finding indicates that the surface crack width might not be the main parameter controlling the initiation of corrosion initiation over time. The maximum stress reached at the reinforcement or the interfacial damage caused during mechanical loading might be a better indicator of a reduction of the initiation period. This statement is also supported by the fact that five load cycles resulted in earlier corrosion compared to specimens subjected to only one load cycle, when a certain load was exceeded.

5. Among the fibres used in this investigation, the addition of $0.75 \%$ by volume of PVA macro-fibres seemed to show a higher improvement in terms of delayed corrosion onset. However, since only a reduced number of specimens presenting large deviations were stud- 


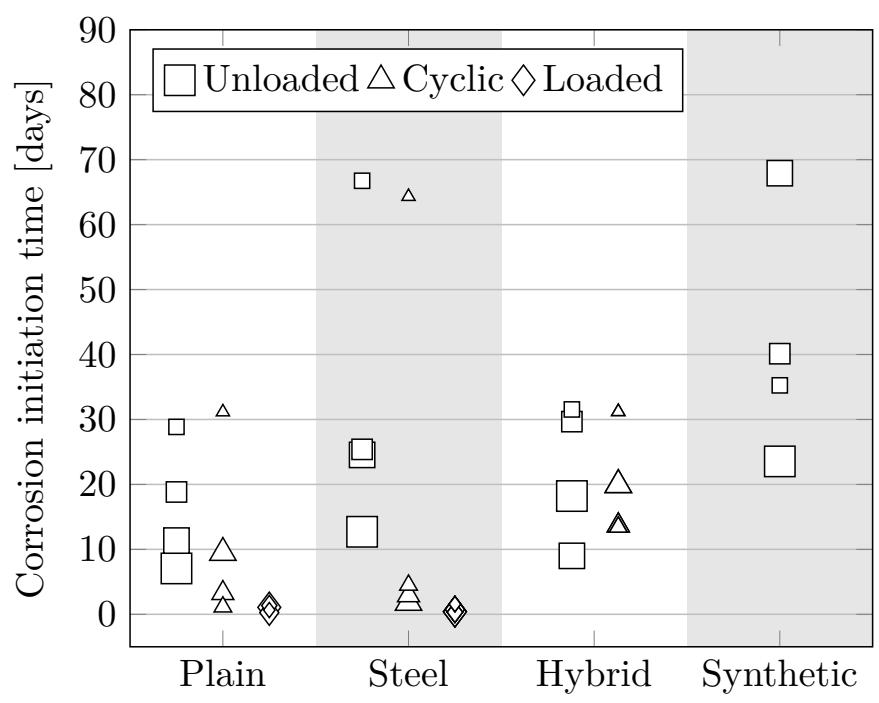

Figure 13: Corrosion initiation times: influence of fibre type and loading conditions. The size of the markers indicate the relative crack width within a series (larger size, wider cracks).

ied, these results were not conclusive. Steel fibres showed better performance for lower load levels, which could be attributed to the damage originating at the interface between fibres and cement paste for large deformations. Hybrid series, combining steel fibres and PVA micro-fibres, showed a better behaviour than steel fibres under cyclic loading and the initiation period seemed to be less sensitive to the load level.

6. Overall, the results here presented, showed that all the beams made of fibre reinforced concrete, independently of the fibre type, exhibited similar or improved behaviour in terms of corrosion initiation times, compared to their plain concrete counterparts.

\section{References}

[1] D. Hobbs, Concrete deterioration: causes, diagnosis, and minimising risk, International Materials Reviews 46 (3) (2001) 117144. doi:10.1179/095066001101528420

[2] K. Tuutti, Corrosion of steel in concrete, CBI Report 4:82, The Swedish Cement and Cocnrete Institute. (1982) 468.

[3] K. Wang, D. C. Jansen, S. P. Shah, A. F. Karr, Permeability study of cracked concrete, Cement and Concrete Research 27 (3) (1997) 381-393. doi:10.1016/S0008-8846(97)00031-8.

[4] C.-M. Aldea, S. P. Shah, A. Karr, Effect of Cracking on Water and Chloride Permeability of Concrete, Journal of Materials in Civil Engineering 11 (3) (1999) 181-187. doi:10.1061/(ASCE) 0899-1561(1999) 11:3(181)

[5] R. Francois, J. Maso, Effect of damage in reinforced concrete on carbonation or chloride penetration, Cement and Concrete Research 18 (6) (1988) 961-970. doi:10.1016/0008-8846(88) 90033-6.
[6] EN 1992-1-1 Eurocode 2: Design of concrete structures - Part 1-1: General rules and rules for buildings (2004).

[7] ACI Committee 318, 318-11: Building Code Requirements for Structural Concrete and Commentary (2011).

[8] A. W. Beeby, Cracking: what are crack width limits for?, Concrete 12 (7) (1978) 31-33.

[9] P. Schieß 1, M. Raupach, Laboratory Studies and Calculations on the Influence of Crack Width on Chloride-Induced Corrosion of Steel in Concrete, ACI Materials Journal 94 (1) (1997) 56-61.

[10] T. E. Maaddawy, K. Soudki, T. Topper, Long-term performance of corrosion-damaged reinforced concrete beams, ACI Structural Journal 102 (5) (2005) 649-656.

[11] T. U. Mohammed, N. Otsuki, M. Hisada, T. Shibata, Effect of Crack Width and Bar Types on Corrosionof Steel in Concrete, Journal of Materials in Civil Engineering 13 (3) (2001) 194-201. doi:10.1061/(ASCE) 0899-1561(2001)13:3(194)

[12] M. Otieno, M. Alexander, H.-D. Beushausen, Corrosion in cracked and uncracked concrete - influence of crack width, concrete quality and crack reopening, Magazine of Concrete Research 62 (6) (2010) 393-404. doi:10.1680/macr.2010.62.6. 393

[13] C. Arya, F. Ofori-Darko, Influence of crack frequency on reinforcement corrosion in concrete, Cement and Concrete Research 26 (3) (1996) 345-353. doi:10.1016/S0008-8846(96)85022-8

[14] A. Poursaee, C. M. Hansson, The influence of longitudinal cracks on the corrosion protection afforded reinforcing steel in high performance concrete, Cement and Concrete Research 38 (8-9) (2008) 1098-1105. doi:10.1016/j.cemconres.2008. 03.018

[15] E. Parant, R. Pierre, F. L. Maou, Durability of a multiscale fibre reinforced cement composite in aggressive environment under service load, Cement and Concrete Research 37 (7) (2007) 11061114. doi:10.1016/j.cemconres.2006.02.021.

[16] S. Yoon, K. Wang, W. Weiss, S. Shah, Interaction between loading, corrosion, and serviceability of reinforced concrete, ACI materials journal 97 (6) (2000) 637-644.

[17] A. Michel, A. Solgaard, B. Pease, M. Geiker, H. Stang, J. Olesen, Experimental investigation of the relation between damage at the concrete-steel interface and initiation of reinforcement corrosion in plain and fibre reinforced concrete, Corrosion Science 77 (2013) 308-321. doi:10.1016/j.corsci.2013.08.019.

[18] T. A. Söylev, R. François, Corrosion of Reinforcement in Relation to Presence of Defects at the Interface between Steel and Concrete, Journal of Materials in Civil Engineering 17 (4) (2005) 447-455. doi:10.1061/(ASCE) 0899-1561(2005) $17: 4(447)$

[19] N. Silva, Chloride Induced Corrosion of Reinforcement Steel in Concrete. Threshold Values and Ion Distributions at the Concrete-Steel Interface, Ph.D. thesis, Chalmers University of Technology, Gothenburg, Sweden (2013).

[20] L. H. Lárusson, Development of Flexible Link Slabs using Ductile Fiber Reinforced Concrete, Ph.D. thesis, Technical University of Denmark (2013).

[21] J. Rapoport, C.-M. Aldea, S. P. Shah, B. Ankenman, A. Karr, Permeability of Cracked Steel Fiber-Reinforced Concrete, Journal of Materials in Civil Engineering 14 (4) (2002) 355.

[22] T. Teruzzi, E. Cadoni, G. Frigeri, S. Cangiano, G. A. Plizzari, Durability aspects of steel fibre reinforced concrete, in: 6th RILEM Symposium on Fibre-Reinforced Cocnretes (FRC) - BEFIB2004, no. September, Varenna, Italy - September 20-22, 2004, pp. 625-634.

[23] H. Mihashi, S. Faiz, U. Ahmed, A. Kobayakawa, Corrosion of Reinforcing Steel in Fiber Reinforced Cementitious Composites, Journal of Advanced Concrete Technology 9 (2) (2011) 159-167.

[24] M. Maalej, S. F. Ahmed, P. Paramasivam, Corrosion Durability and Structural Response of Functionally-Graded Concrete Beams, Journal of Advanced Concrete Technology 1 (3) (2003) 307-316. doi:10.3151/jact.1.307

[25] J. Grubb, J. Blunt, C. Ostertag, T. Devine, Effect of steel microfibers on corrosion of steel reinforcing bars, Cement and Concrete Research 37 (7) (2007) 1115-1126. doi:10.1016/j. 
cemconres.2007.04.012

[26] B. Kim, a. J. Boyd, J.-Y. Lee, Effect of transport properties of fiber types on steel reinforcement corrosion, Journal of Composite Materials 45 (8) (2010) 949-959. doi:10.1177/ 0021998310380286

[27] J. Matsumoto, K. Horiguchi, T. Maruya, A Study on Durability of Reinforced Concrete using Steel Fibres under the Chloride Attack Condition, in: 8th International Symposium on Fibre Reinfored Concrete: Challenges and Opportunities - BEFIB2012, Guimarães, Portugal, 2012.

[28] A. K. Someh, N. Saeki, The Role of Galvanized Steel Fibers in Corrosion-Protection of Reinforced Concrete, Proceedings of Japan Concrete Institute 19 (1) (1997) 889-894.

[29] S. Kakooei, H. M. Akil, A. Dolati, J. Rouhi, The corrosion investigation of rebar embedded in the fibers reinforced concrete, Construction and Building Materials 35 (2012) 564-570. doi:10.1016/j.conbuildmat.2012.04.051

[30] A. Al-Tayyib, M. Mesfer, A. Zahrani, Corrosion of steel reinforcement in polypropylene fiber reinforced concrete structures, ACI Materials Journal 87 (2). doi:10.14359/1895

[31] M. Sappakittipakorn, N. Banthia, Corrosion of Rebar and Role of Fiber Reinforced Concrete, Journal of Testing and Evaluation 40 (1). doi:10.1520/JTE103873

[32] C. P. Ostertag, J. Blunt, Effect of crack control in hybrid fiber reinforced concrete composites on corrosion rate of steel reinforcing bars, in: Fracture Mechanics of Concrete and Concrete Structures - Assessment, Durability, Monitoring and Retrofitting of Concrete structures, no. mm, Seoul, Korea Concrete Institute, 2010, pp. 894-900.

[33] A. Niş, T. A. Söylev, A. O. Pehlivan, N. O. Zihnioglu, T. Özturan, Effect of crack opening under cyclic loading on the reinforcement corrosion in concrete with and without steel fiber, in: The European Corrosion Congress, EUROCORR 2012, Istanbul, Turkey, 2012, p. CD.

[34] E. Standard, EN 14651:2005 Test method for metallic fibered concrete - Measuring the flexural tensile strength ( limit of proportionality ( LOP ), residual ) (2005).

[35] EN 12390-2:2001 Tesing hardened concrete - Part 2: Making and curing specimens for strength tests (2001).

[36] EN 12390-3:2003 Testing hardener concrete. Part 3: Compressive strength of test spcimens (2003).

[37] Nordtest Method, NT BUILD 492 - Chloride Migration Coefficient from Non-Steady-State Migration Experiments, Tech. rep. (1999).

[38] S. Jaffer, C. Hansson, The influence of cracks on chlorideinduced corrosion of steel in ordinary Portland cement and high performance concretes subjected to different loading conditions, Corrosion Science 50 (12) (2008) 3343-3355. doi: 10.1016/j.corsci.2008.09.018.

[39] CEN, EN 206-1 Concrete - Part 1: Specification, performance, production and conformity, Tech. rep. (2000).

[40] L. Pawlick, G. Stoner, G. Clemeña, Development of an embeddable reference electrode for reinforced concrete structures, Tech. rep., Virginia Transportation Research Council (1998).

[41] ASTM C876-09, Standard Test Method for Corrosion Potentials of Uncoated Reinforcing Steel in Concrete, Tech. rep. (2012). doi:10.1520/C0876-09.2

[42] B. Elsener, C. Andrade, J. Gulikers, R. Polder, M. Raupach, Half-cell potential measurements. Potential mapping on reinforced concrete structures, Materials and Structures 36 (7) (2003) 461-471. doi:10.1007/BF02481526

[43] A. Bentur, S. Wu, N. Banthia et al., Fiber-matrix interfaces, in: A. N. Reinhardt, H.W. (Eds.), High Performance Fiber Reinforced Cement Composites 2, E \& FN Spon, London, UK, 1996, pp. 149-191.

[44] S. F. Lee, S. Jacobsen, Study of interfacial microstructure, fracture energy, compressive energy and debonding load of steel fiber-reinforced mortar, Materials and Structures 44 (8) (2011) 1451-1465. doi:10.1617/s11527-011-9710-4

[45] B. Kim, J.-Y. Lee, Relationships between mechanical and transport properties for fiber reinforced concrete, Journal of Com- posite Materials 46 (13) (2011) 1607-1615. doi:10.1177/ 0021998311421691.

[46] L. Tang, Y. Fu, A. León, Rapid Assessment of Reinforcement Corrosion in Concrete Bridges, Tech. rep., CBI Betonginstitutet (2010).

[47] K. Tammo, A new approach to crack control for reinforced concrete. An investigation of crack widths close to the reinforcement and the correlation to service life, Ph.D. thesis, Lund University, Sweden.

[48] A. Bentur, S. Mindess, Fibre reinforced cementitious composites, 2nd Edition, Taylor \& Francis, Abingdon, United Kingdom, 2007. 